\title{
Kvėpavimo takų uždegimas sergant sunkia nealergine eozinofiline astma
}

\author{
AIRWAY INFLAMMATION IN SEVERE NON-ALLERGIC EOSINOPHILIC ASTHMA
}

\author{
VIRGINIJA KALINAUSKAITĖ-ŽUKAUSKE் ${ }^{1}$, IEVA JANULAITYTE்², ANDRIUS JANUŠKEVIČIUS², \\ KESTUTIS MALAKAUSKAS ${ }^{1,2}$ \\ ${ }^{1}$ LSMU MA Pulmonologijos klinika, ${ }^{2}$ LSMU MA Pulmonologijos klinikos Pulmonologijos laboratorija
}

\begin{abstract}
Santrauka. Eozinofiline astma yra atskiras ligos fenotipas, pasižymintis išreikštu eozinofiliniu kvèpavimo taku uždegimu. Sunki eozinofilinè astma paprastai yra nealerginès kilmès, komplikuotos klinikinès eigos, jai būdinga vèlyva pradžia, dažni paūmèjimai, atsparumas gliukokortikoidams, nereti ir negalios atvejai. Todèl šiam astmos fenotipui skiriamas ypatingas dèmesys: viena iš galimu priežasčiu - nepakankamai valdomas eozinofilinis uždegimas. Apžvalgoje pateikiami apibendrinti duomenys apie nealerginès kilmés kvépavimo taku eozinofilinio uždegimo išsivystymo kelius, biologiniu žymenu svarba ir poreikį, naujausias gydymo galimybes.

Reikšminiai žodžiai: eozinofilas, eozinofilinis uždegimas, sunki nealergine eozinofilinè astma, biologiniai žymenys. Summary. Eosinophilic asthma is one of multiple phenotypes of asthma based on the eosinophil-rich inflammation in the airways. Severe eosinophilic asthma usually is non-allergic, associated with severe clinical course, late-onset disease, with frequent exacerbation and steroid refractoriness, not so rare with disability cases. Therefore, the focus on this asthma phenotype is not in vain: this may be related to insufficiently managed eosinophilic inflammation. The review provides generalized data on the mechanisms of airway non-allergic eosinophilic inflammation development, the importance of biological markers, the latest treatment options.
\end{abstract}

Key words: eosinophil, eosinophilic inflammation, severe non-allergic eosinophilic astma, clinical biomarkers.

\section{IVADAS}

Astma yra lètinè kvépavimo takų uždegimo liga, pasižyminti skirtingais patofiziologiniais ligos išsivystymo mechanizmais ir su tuo susijusia skirtinga klinikine eiga bei prognoze. Pagal Europos respiratologų (angl. European Respiratory Society) ir Amerikos krūtinès draugijų (angl. American Thoracic Society) sutarimą, astma laikoma sunkia, jei nepavyksta pasiekti ligos simptomų kontrolès skiriant dideles įkvepiamụjų gliukokortikoidų (iGK) dozes kartu su kitu kontroliuojamuoju vaistu ir (arba) sisteminiais gliukokortikoidais (sGK) $[1,2]$. Nors sunkia astma serga tik apie 5-10 proc. visų sergančiųjų astma, tačiau pastarųjų gydymui tenka išties reikšminga medicininių išlaidų dalis dèl komplikuotos ligos eigos, dažnų paūmèjimų, stacionarinio gydymo poreikio. Nukenčia sergančiojo socialinis gyvenimas, bendra su sveikata susijusi gyvenimo kokybè $[1,3,4]$. Pastarąji dešimtmetį išskirtinis demesys skiriamas sunkiai eozinofilinei astmai ir jos patogenezei, nes šis astmos fenotipas kelia didžiausia rūpestị gydant ir siekiant kontroliuoti astmos simptomus, retinant ligos paūmèjimus [5]. Šioje apžvalgoje apibendrinami duomenys apie eozinofilų sukeliamą kvèpavimo takų uždegimą sergant sunkia nealergine eozinofiline astma, biologinių žymenų panaudojimo galimybes klinikineje praktikoje siekiant individualizuoti sergančiųjų gydymą.

\section{EOZINOFILŲ STRUKTŪRA IR FUNKCIJOS}

Sergant sunkia eozinofiline astma pagrindinis vaidmuo ligos patogenezèje tenka eozinofilams dèl žymiai padidejusio jų kiekio kraujyje ir plaučių audinyje bei lètinio uždegimo fone vykstančių struktūrinių kvèpavimo takų, plaučių audinio pokyčių [6].

Eozinofilai - tai cirkuliuojantys granuliocitai, kurie kartu su kitomis baltosiomis kraujo ląstelèmis gaminami kaulų čiulpuose. Kad eozinofilas subręstų ir gebètu atlikti savo funkcijas (ne visuomet palankias organizmui), turi įvykti daug biocheminių ir fiziologinių procesų. Šios imuninès ląstelès kaulų čiulpuose pradeda vystytis iš pluripotentinių CD34+ progenitorinių kamieninių ląstelių. Eozinofilų linijos besivystančias ląsteles veikia transkripcijos veiksniai. Vienas pagrindinių - GATA-3 [7]. Šis veiksnys skatina antrojo tipo T ląstelių pagalbininkių (Th2) citokinų gamybą, iskaitant interleukinus (IL), svarbius vystantis eozinofilams. Daugiausia GATA-3 išskiria Th2 ir mažesniu kiekiu antrojo tipo limfoidinès ląstelès (ILC2) $[6,8]$. Tai pagrindinis Th2 ląstelių diferenciacijos reguliatorius, kuris kontroliuoja IL-4, IL-5 ir IL-13 raišką [6]. Ankstyvoje fazejje eozinofilai kaulų čiulpuose diferencijuojasi veikiant granuliocitų-makrofagų kolonijas stimuliuojamajam veiksniui (GM-CSF), IL-3, IL-33, ittakos turi progenitorinių ląstelių ST2 receptorių raiška [9]; vèlesnèse fazèse - IL-5 [6, 8], kurio gamybai ir 


\section{Moksliniai darbai ir apžvalgos}

receptorių IL-5Ra raiškai pirmtakų ląstelių paviršiuose svarbus IL-33 [9]. Tyrimų su pelemis metu pastebèta, kad, stingant IL-33, IL-5, ST2 ir IL-5Ra receptorių, sutrikdoma eozinofilopoezè [9].

Eozinofilai prieš patekdami ị kraujotaką, gamina ir kaupia antrines baltymines granules, svarbias tolesniam ląstelių išgyvenimui ir funkcionavimui. Galutinè diferencijacija ịvyksta veikiant IL-5 [7]. Subrendę eozinofilai sudaro 1-3 proc. visų baltụjų kraujo ląstelių [3]. Pilnai subrendę eozinofilai yra 12-17 $\mu$ dydžio ląstelès, turinčios dviejų segmentų branduolius, dideles acidofilines citoplazmines granules, rodančias jų afinitetą rūgštims (1 pav.). Ląstelès citoplazmoje daug cheminių mediatorių, kurie išskiriami aktyvavus subrendusi eozinofilą ir vykstant jo degranuliacijai. Iš kaulų čiulpų ị kraujotaką patekę eozinofilai gali išgyventi iki 8-12 val., tačiau galutinis jų migracijos taškas yra audiniai [10], kuriuose, nesant stimuliacijos, išlieka gyvybingi iki 8-12 dienų [11]. Normos atveju eozinofilų randama smegenyse, čiobrialiaukèje, apatinejje virškinamojo trakto dalyje, kiaušidėse, gimdoje, blužnyje ir limfmazgiuose, tačiau jų beveik nèra plaučiuose, odoje, stempleje ir kai kuriuose kituose vidaus organuose [12]. Todèl eozinofilų kiekio padidejjimas, pvz., plaučių audinyje, yra neabejotinos ligos požymis ir aiškinama subrendusių eozinofilų migracija iš kraujotakos ị uždegimines audinių zonas [6].

Eozinofilų migracija iš kraujotakos ị audinius vyksta dalyvaujant endotelio sukibimo (adhezinèms) molekulèms: kraujagyslių ląstelių sukibimo molekule ir jos ligandas-1 (VCAM-1) bei tarpląstelinè adhezijos molekule ir jos ligandas-1 (ICAM-1), ir periostinui [6]. Eozinofilai skverbiasi iš kraujotakos ị kvèpavimo takus ir juos infiltruoja. Šiame etape svarbūs antrojo tipo uždegimo citokinai - IL-4 ir IL-13, didinantys chemokinų-eozinofilų chemoatraktantų (iskaitant ir CCL11, CCL24, CCL26) gamybą. IL-4 ir IL-13 didina VCAM-1 raišką endotelio ląstelèse, o tai gerina eozinofilų sukibimą su endotelio ląstelemis ir migraciją ị kvèpavimo takus (per VCAM-1 ir integrinų a4 sąveiką) [13, 14].

Pagrindinị vaidmeni eozinofilai atlieka po aktyvacijos stimulu, kai ịvyksta jų citolizè ir išskiriamos eozinofilinès granulès. Pastarosios atsakingos už ligando sukeltą eozinofilinių toksinų sekreciją bei sukelia struktūrinę ląstelių pažaidą $[6,8]$. Manoma, kad eozinofilų granulių raiška reguliuojama nekoduojančio RNR-EGOT geno (eozinofilo granulès ontogenezès transkripto genas, koduojantis ne baltymus, bet ilgają nekoduojamą RNR molekulę) [15].

Po aktyvacijos eozinofilai geba atlikti šias pagrindines efektorines funkcijas [16-18]:

- Citotoksinių baltymų gamyba ir išskyrimas degranuliacijos metu: didysis pagrindinis baltymas, eozinofilų katijoninis baltymas, eozinofiluc peroksidazè, eozinofilų išskiriamas neurotoksi-

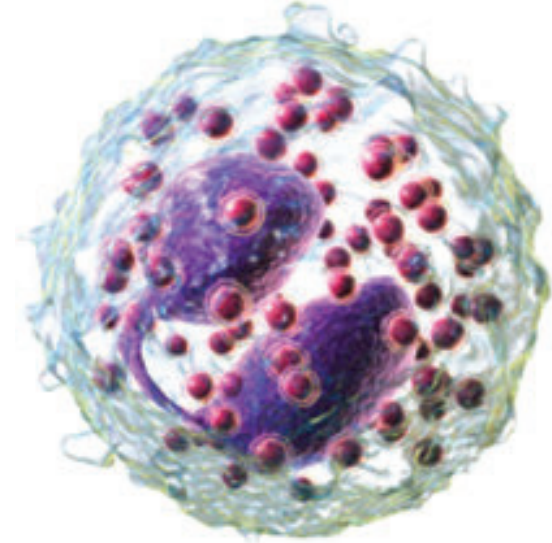

1 pav. Eozinofilo anatominè 3D struktūra (http://leucocitos.org/eosinofilos/)

nas. Didysis pagrindinis baltymas, eozinofilinè peroksidazè ir eozinofilinis katijoninis baltymas yra toksiški daugeliui audinių [18].

- Suformuojamos reaktyviosios deguonies formos: hipobromitas, superoksidas ir peroksidas (hipobrominè rūgštis, kurią iš esmès gamina eozinofilų peroksidazè).

- Sintetinami lipidų tarpininkai (mediatoriai), pvz., eukozanoidai (leukotrienai, pvz., LTC4, LTD4, LTE4; prostaglandinai, pvz., PGE2).

- Gamina ir, prireikus, išskiria fermentus, pvz., elastazę.

- Išskiria augimo veiksnius, pvz., transformuojamąji augimo veiksnį (TGF) beta, kraujagysliu endotelio veikimo veiksnị (VEGF) ir trombocitu kilmès augimo veiksnị (PDGF); citokinus, pvz., IL-1, IL-2, IL-4, IL-5, IL-6, IL-8, IL-13 ir naviko nekrozès veiksni (angl. Tumor Necrosis Factor, TNF) alfa.

\section{EOZINOFILU MIGRACIJOS [ KVĖPAVIMO TAKUS PRINCIPAI IR KLINIKINĖS PASEKMĖS}

Kvėpavimo takuose eozinofilų kiekis paprastai pakinta dẻl uždegimo ir suintensyvejjusios ląstelių migracijos, sąlygotos daugybès veiksnių, kurių pagrindiniai yra putliosios, T ir B ląstelès bei jų išskiriami citokinai (2 pav.). Sistemineje kraujotakoje esantys eozinofilai i kvèpavimo takus geba patekti adhezijos ir migracijos keliu per bronchų kraujagyslių endoteli [10]. Eozinofilų migracija vyksta sąveikaujant jų paviršiuje esantiems integrinams (svarbiausi jų - $\alpha 4 \beta 1$, $\alpha \mathrm{M} \beta 2$ ) su kraujagyslių endotelio ląstelių paviršiaus adhezijos receptoriais, tarp jų: P-selektinas, P-selektino glikoproteino ligandas-1 ir vèlyvo aktyvavimo antigeno/ kraujagyslių ląstelių sukibimo molekulè, VCAM-1 ligandas. Nustatyta, kad VCAM-1 ir P-selektino raišką padidina IL-4 ir IL-13. Eozinofilų telkimasis kvèpavimo takuose kontroliuojamas chemokinų CCL5, 7, 11, 13, 15, 24 ir 26 bei jų receptorių CCR3, Th2 ląstelių 


\section{Moksliniai darbai ir apžvalgos}

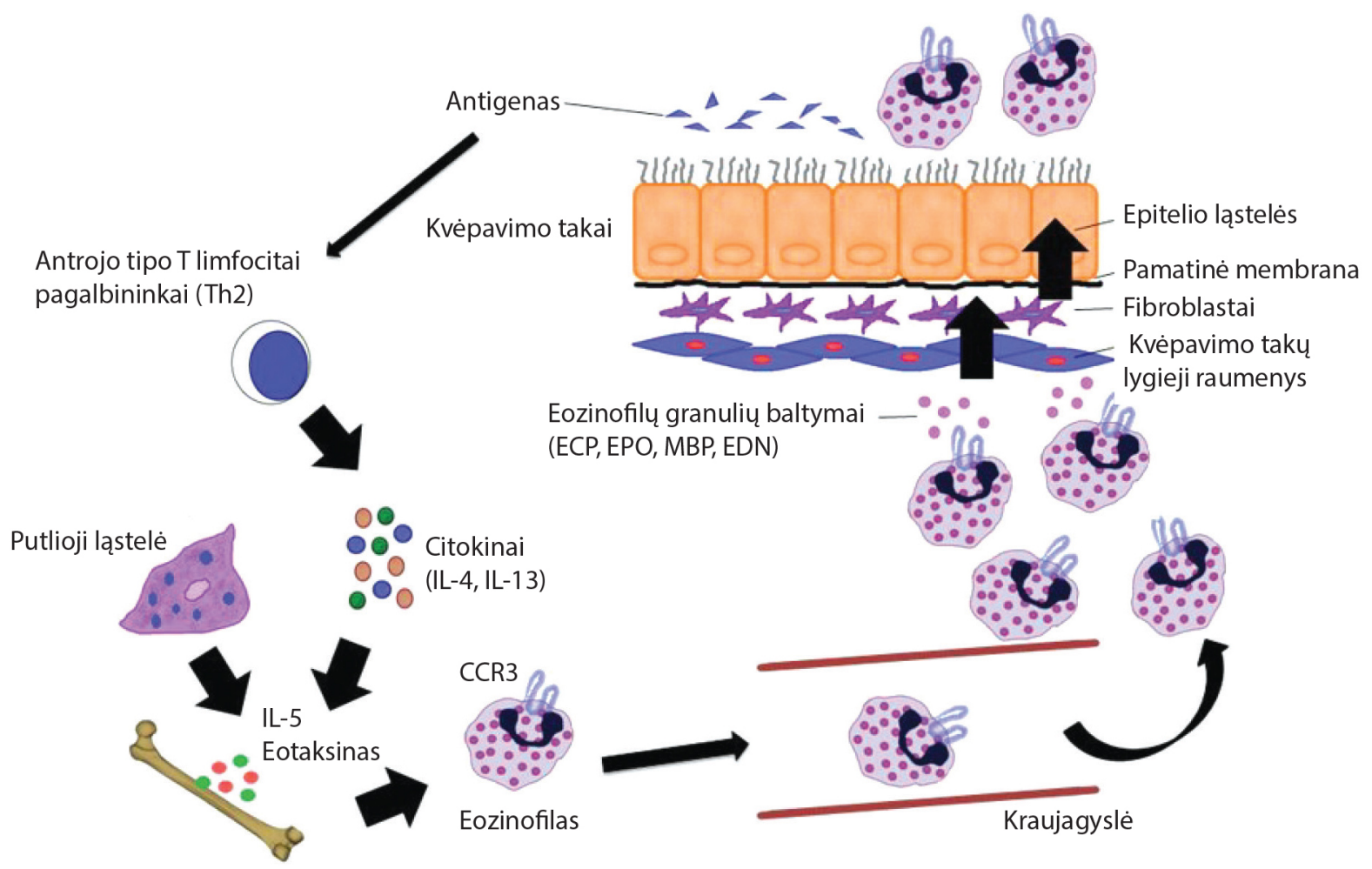

Eozinofilų išsiskyrimas

iš kaulų čiulpu

2 pav. Eozinofilų migracija iš sisteminès kraujotakos ị kvèpavimo takus [22]

IL-4 - interleukinas 4, IL-5 - interleukinas 5, IL-13 - interleukinas 13, CCR3 - CC chemokinų receptorius, Th2 - T ląstelès pagalbininkès 2; ECP (angl. Eosinophil cationic protein), EPO - eozinofilinè peroksidazè (angl. Eosinophil Peroxidase), MBP - didysis pagrindinis baltymas (angl. Major Basic Protein), EDN - iš eozinofilų kilęs neurotoksinas (angl. Eosinophil Derived Neurotoxin)

chemoatraktanto receptoriaus homologinių molekulių (CRTh2), prisijungiančių prostaglandiną D2 (PGD2). PGD2 veikia kaip eozinofiluc chemoatraktantas, taip pat didina CCR3 chemokinu poveiki. Aktyvintos putliosios ląstelès yra pagrindinis PGD2, išskiriamo tiek nuo IgE priklausomos, tiek nepriklausomos aktyvacijos metu, šaltinis [8]. Uždegimo metu eozinofilu kaupimąsi kvèpavimo takuose skatina ir kvépavimo takų epitelio ląstelių, eozinofilu, fibroblastų išskiriamas periostinas [19]. Tai užląstelinio užpildo baltymas, kuriam jungiantis su eozinofilu $\alpha M \beta 2$ ir $\alpha 4 \beta 1$ integrinais, skatinama eozinofilu adhezija ir telkimasis kvèpavimo takuose [20,21]. Aktyvuoti eozinofilai geba greitai reaguoti ị stimulą ir mažiau nei per 1 val. išskirti imunomoduliuojamąsias medžiagas - daugiau kaip 35 rūšiu citokinus, augimo veiksnius ir chemokinus [17].

Gausi audinių infiltracija aktyvuotais eozinofilais galiausiai sukelia struktūrinius bronchų pokyčius. Naujausi tyrimai rodo, kad migruodami eozinofilai gali tiesiogiai adhezijos būdu per išskiriamus integrinus prisitvirtinti prie bronchų lygiųjų raumenų ląstelių bei skatinti jas išskirti TGF- $\beta 1$, WNT-5a ligandą, užląstelinio užpildo baltymus - fibronektiną ir kolageną, skatinti bronchų lygiụjų raumenų ląstelių proliferaciją [22]. Tai sukelia kvèpavimo takų remodeliaciją. Tačiau šiuo metu eozinofilų prisijungimą prie bronchų ly- giụjų raumenų ląstelių paviršiaus molekulių ICAM-1 ir VCAM-1 pavyksta slopinti tik in vitro sąlygomis blokuojant eozinofilų integrinus, tokiu būdu kontroliuojant bronchų lygiưjų raumenų ląstelių proliferaciją [20]. Spejjama, kad sergančiųjų sunkia eozinofiline astma eozinofilai yra žymiai aktyvesni, lyginant su lengvesne astma sergančiųjų eozinofilais dèl labiau išreikštų paviršinių $\alpha 4 \beta 1$ ir $\alpha \mathrm{M} \beta 2$ integrinų bei didesnès TGF- $\beta 1$ gamybos, stabilesnès adhezijos bei didesnès TGF- $\beta 1, W N T-5 a$, kolageno ir fibronektino genų raiškos bronchų lygiụjų raumenų ląstelèse [22].

Eozinofilų migraciją iš periferinio kraujo į kvejpavimo takus sudètinga valdyti, taigi, lengviau kontroliuoti eozinofilų sukeliamą vietinį uždegimą kvėpavimo takuose [22]. Vienas iš būdų - blokuoti eozinofilų kontaktą su bronchų lygiụjų raumenų ląstelèmis arba užląstelinio užpildo baltymais.

\section{NEALERGINĖS KILMĖS EOZINOFILINIS UŽDEGIMAS SERGANT SUNKIA EOZINOFILINE ASTMA}

Eozinofilinis uždegimas gali būti tiek alerginès, tiek nealerginès kilmès. Alerginès kilmès eozinofilinio uždegimo mechanizmai yra gana plačiai ištyrinèti, tačiau eozinofilinis uždegimas be atopijos ir ji sukeliantys veiksniai nepakankamai ištirti. 


\section{Moksliniai darbai ir apžvalgos}

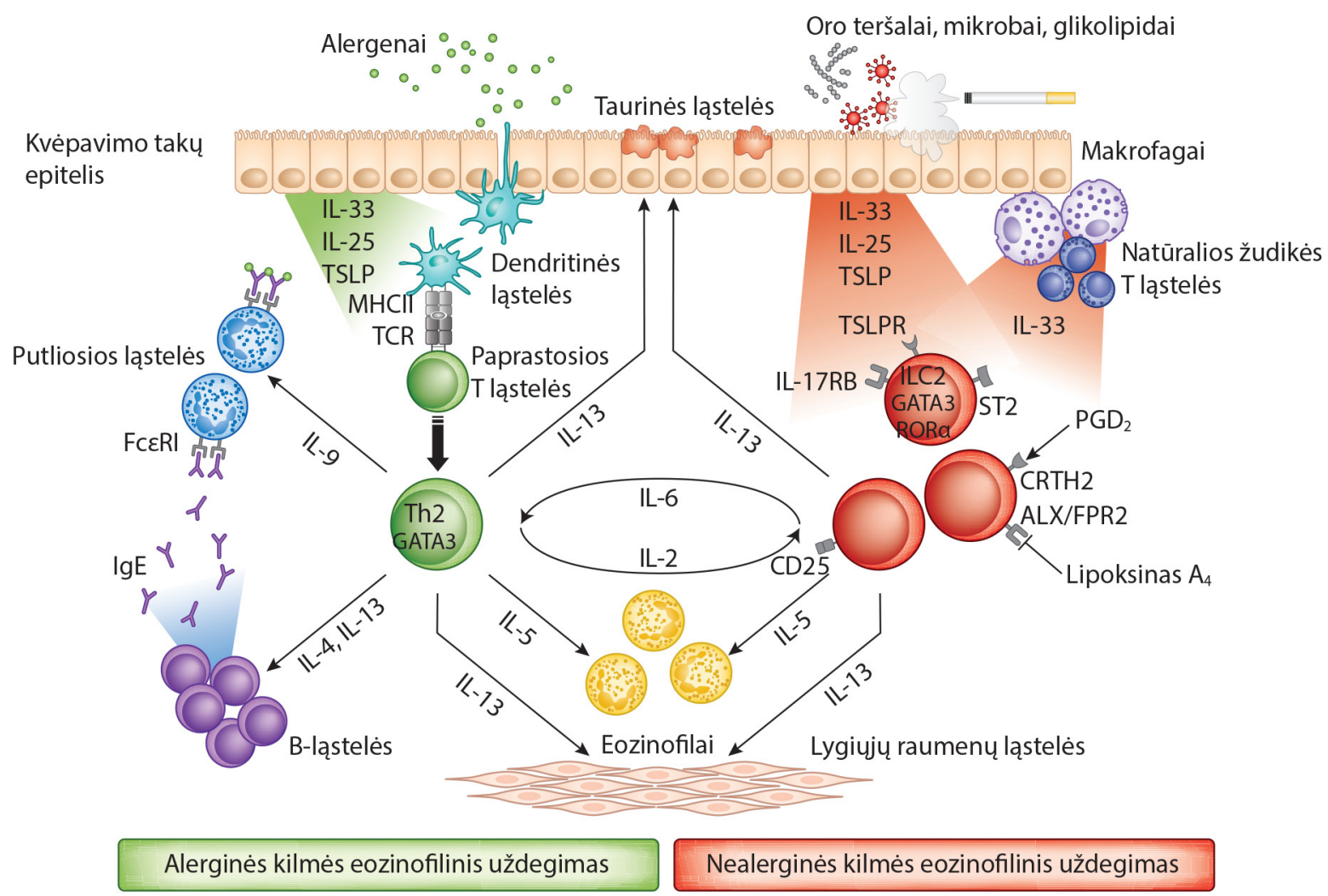

3 pav. Skirtingi eozinofilinio uždegimo patogenetiniai keliai sergant astma [34]

CRTH2 - chemoatraktanto receptoriaus homologinè molekulè, išreikšta Th2 ląstelèse; ALX / FPR2 - lipoksino A4 receptorius; FcદRI - didelio afiniteto lgE receptorius; GATA3 - GATA surišantis baltymas 3; PGD2 - prostaglandinas D2; RORa - su retino rūgštimi susiję receptoriai našlaičiai.

Eozinofilinès astmos metu kvèpavimo takuose dominuoja antrojo tipo uždegimas. Antrojo tipo uždegimui būdingas eozinofilų, putliųjų ląstelių, bazofilų, Th2 ląstelių, ILC2 ir IgE gaminančių B ląstelių kaupimasis. Pagrindiniai antrojo tipo uždegimo tarpininkai ir citokinai - IL-4, IL-5 ir IL-13 [24]. Eozinofilinio astmos fenotipo patogenezès pagrindas išreikšta eozinofilija, kai kraujyje ir (arba) audiniuose randami dideli eozinofilų kiekiai. Kraujyje eozinofilija apibrěžiama kaip šių ląstelių skaičiaus padidejimas daugiau kaip $0,5 \times 10^{9} / 1$, audiniuose - priklausomai nuo fiziologiškai randamo jų kiekio [25]. Sergant eozinofiline astma, plaučių audinyje randama daug eozinofilų, sukeliančių lètinị uždegimą ir pažeidžiančių plaučių audinị, dèl to ligos eiga ir gydymas tampa komplikuoti. Pastebètas eozinofilijos ryšys su astmos sunkumu [26].

Eozinofiliné astma ịprastai yra vèlyvos pradžios, dažniausiai susijusi su letiniu rinosinusitu, nosies polipais, dažniausiai yra sunki ir nealerginès kilmès [27]. Šio fenotipo astma sergantiems asmenims, nepaisant skiriamo gydymo iGK, tiek kraujyje, tiek plaučių audinyje nuolat persistuoja eozinofilija, dažnas sGK poreikis dèl nepakankamai kontroliuojamų arba nekontroliuojamų ligos simptomų $[2,25,27,28]$.
Neseniai atliktame tyrime, kurio metu siekta išsiaiškinti nealerginès kilmés eozinofilinio kvèpavimo taku uždegimo mechanizmus, nustatyta, kad sergant lètiniu rinosinusitu su išreikšta eozinofilija nosies polipuose aptiktas padidèjęs ILC2, pagrindinių nespecifinių igimtų imuniteto efektorių, kiekis [29]. Po stimuliacijos užkrūčio liaukos stromos limfopoetinu (TSLP) ir IL-33, ILC2 ląstelès pradèjo gaminti su Th2 uždegimu susijusius citokinus, ịskaitant didelius IL-5 ir IL-13 kiekius bei, kiek mažiau, IL-4 [30, 31]. Padidèjusi IL-5 gamyba iš dalies gali paaiškinti eozinofilinio uždegimo pasireiškimą sunkios nealerginès eozinofilinès astmos metu. Kadangi, sergant sunkia astma, kvépavimo takuose padideja epitelio citokino TSLP ir lipoksino A raiška, dèl to sumažèja ILC2 išskiriamo IL-13 kiekis, o nevaldoma ILC2 aktyvacija gali lemti refrakterinę eozinofiliją sergantiesiems sunkia nealergine astma [32]. Nustatyti ir genai, kurie siejami su ILC2 vystymusi ir aktyvacija: ILC2 diferenciacijai labai svarbus ROR-1-a koduojamasis genas, ir genai, kurie koduoja IL-33 bei IL-1 receptorių tipą 1, kuris yra IL-33 receptorių komplekso (dar vadinamo ST2) dalis, medijuojantys IL-33 signalinį kelią ir aktyvuojantys ILC2 [33].

Sergant astma, eozinofilinį kvẻpavimo takų uždegimą sukeliančio IL-5 gamyba gali vykti dviem skirtingais ir 


\section{Moksliniai darbai ir apžvalgos}

vienas nuo kito nepriklausomais patogenetiniais keliais: alergenui specifiniams paprastiesiems $\mathrm{T}$ limfocitams (angl. naive-T cells) virstant i Th2 ląsteles, gaminančias savo citokinų spektrą, arba nuo alergeno nepriklausomas igimtų ILC2 ląstelių, gaminančių savo citokinus, kelias (3 pav.). Panaudojant eksperimentini alerginès astmos modeli, nustatyta, kad pelèms, kurioms stinga IL-13, ILC2 ląstelès sukelia kvèpavimo takų hiperreaktyvumą, stebima eozinofiline infiltracija. Pacientams, sergantiems astma, IL-13 ILC2 ląstelès gamina kaip atsaką ì putliụjų ląstelių sekretuojamą PGD2, todèl jo receptoriai gali būti slopinami tiek alerginès, tiek nealerginès astmos atvejais. Tačiau dar nepakankamai ištirta, ar ILC2 ląstelių kiekis kraujyje ir apatiniuose kvepavimo takuose koreliuoja su specifiniais astmos fenotipais [34]. Terapiniu požiūriu įdomu išsiaiškinti, ar ILC2 ląstelès siejamos su refrakteriškumu GK, juo labiau - ar blokuojant/keičiant ILC2 patogenetinius kelius, receptorių raišką, išskiriamus citokinus, chemokinus, būtų galima pasiekti geresnių sunkios eozinofilinès nealerginès astmos gydymo rezultatų.

Eozinofilinị uždegimą, sergant astma, sukelia du skirtingi patogenetiniai keliai: alerginès astmos atveju dendritinès ląstelès pateikia antigeną CD4 + T ląstelèms, indukuoja Th2 ląsteles, kurios gamina IL-4, IL-5 ir IL-13, o tai sąlygoja antikūnų gamybos B ląstelèse perjungimą iš IgM/IgG ị IgE, kvèpavimo takų eozinofiliją ir gleivinès hipersekreciją. Nealerginès eozinofilinès astmos atveju oro teršalai, mikrobai ir glikolipidai sukelia iš epitelio ląstelių kilusių citokinų, ìskaitant IL-33, IL-25 ir TSLP, išskyrimą, kurie aktyvuoja ILC2 ląsteles nuo antigeno nepriklausomu būdu per atitinkamus savo receptorius (IL-17RB, ST2 ir TSLPR). Aktyvuotos ILC2 ląstelès gamina didelius IL-5 ir IL-13 kiekius, dèl to atsiranda eozinofilija, gleivinès hipersekrecija ir kvejpavimo takų hiperreaktyvumas.

Neigiamas eozinofilinio uždegimo pasekmes lemia ir ilgesnè eozinofilų išgyvenamumo trukmè dèl užtrukusios apoptozès, prailgejusio eozinofilų toksinių mediatorių išskyrimo laiko. Normos atveju eozinofilus, ìvykus programuotai jų žūčiai (apoptozei), pašalina makrofagai nesukeliant imuninio atsako. Esant uždelstai apoptozei, sudaromos palankios sąlygos persistuoti eozinofiliniam uždegimui ir šiame procese svarbią vietą užima IL-3, IL-5 bei GM-CSF [35].

Idomu ir tai, kad atliekant tyrimus su pelèmis, plaučių audinyje aptikta išskirtinai ilgiau gyvuojančių eozinofilų, kurių atliekamos funkcijos dar nepakankamai ištirtos, tačiau genų raiškos analizès duomenimis, jie pasižymi stipresnèmis reguliacinėmis savybėmis [36]. Šie eozinofilai priskiriami parenchiminėms ląstelèms, pasižyminčiomis Th2 imuninị atsaką slopinamosiomis savybemis, kurioms IL-5 neturi tokio stipraus poveikio. Atlikus bronchų provokaciją su namų dulkių erkèmis, audinių eozinofilų savybės išliko nepakitusios [36].
Kalbant apie refrakteriškumą gydant GK sergančiuosius sunkia astma, labiausiai tikètina priežastis - GK receptorių disfunkcija ir histono deacetilazès aktyvumo sumažejjimas [28]. Gydant GK, uždegimas slopinamas reguliuojant transkripcijos ir negenominius kelius. Reguliuojant transkripciją, GK prisijungia prie GK receptorių (GK-R), o vèliau kompleksai susiejami su tikslinio geno promotoriaus sritimi. Taip aktyvuojama arba nuslopinama genų transkripcija [37, 38]. Negenominis steroidų poveikis apima antrinius signalų nešiklius ir ne klasikinius receptorius [34]. Sergant sunkia astma, branduolyje yra sumažèjęs GK-R jungimosi afinitetas ir sutrikusi branduolio GK prisijungiančių GK-R translokacija [39], palyginti su GK jautria astma sergančiaisiais. Norint sukelti GK-GK-R prisijungimo prie promotoriaus genų slopinimą, histonas turi būti acetilintas, o būtent atsparia GK astma sergantiesiems ir būna sutrikę ir žymiai silpnesni histono acetilinimo procesai [39]. Be to, šiems pacientams randama ir padidejusi neprisijungiančių GK-R izoformų GR $\beta$ raiška, dèl to sumažèja steroidus prisijungiančių GKRa kiekis [39].

\section{PATOGENEZĖS SKIRTUMU NULEMTI SUNKIOS EOZINOFILINĖS ASTMOS GYDYMO SAVITUMAI}

Sergant sunkia astma, gydymo pagrindas yra 4-5 gydymo pakopų vaistai (vidutiné arba didelè iGK dozė kartu su ilgo veikimo $\beta 2$ agonistu be (arba su) ilgo veikimo muskarino receptorių blokatoriaus, su (arba be) leukotrienų receptorių blokatoriumi, pagal reikalą pridedant sGK, anti-IgE arba anti-IL-5). Remiantis šiuo metu esamais tyrimų duomenimis, panašiausia, kad sergantiesiems sunkia, GK atsparia astma pastarosios patogenezejje pagrindinis vaidmuo tenka IL-5/ IL-33 signaliniam keliui $[28,40]$. Šiems pacientams veiksmingiausias gydymas anti-IL-5 vaistais, kurie blokuoja IL-5 signalinị kelią. Pastebèta, kad sergant šio fenotipo astma, anti-IL-5 vaistai (mepolizumabas, benralizumabas, reslizumabas) žymiai sumažina eozinofilų kiekį, astmos paūmėjimų skaičių, mažesnis geriamųjų GK poreikis, neprarandant astmos simptomų kontrolès [41-45].

Daugelis eozinofilų funkcijų valdomos IL-5. Stingant jo arba kitų aktyvių eozinofilinių citokinų, eozinofilai greitai apoptozuoja. Mepolizumabas ir reslizumabas yra IL-5 antagonistiškai veikiantys monokloniniai antikūnai, neutralizuojantys IL-5 ir neleidžiantys jungtis prie IL-5 receptorių, esančių ląstelių paviršiuje. Slopinamas IL-5 signalinis kelias ir IL-5 bioaktyvumas, mažinama eozinofilų gamyba kaulų čiulpuose ir jų išgyvenimas. Tuo tarpu benralizumabas jungiasi prie IL-5 receptoriaus a grandinès (IL-5R $\alpha$ ) ir blokuoja IL-5 prisijungimą. Minèti receptoriai randami subrendusių eozinofilų, eozinofilų linijos progenitorių ląstelių ir bazofilų paviršiuose (4 pav.). 


\section{Moksliniai darbai ir apžvalgos}

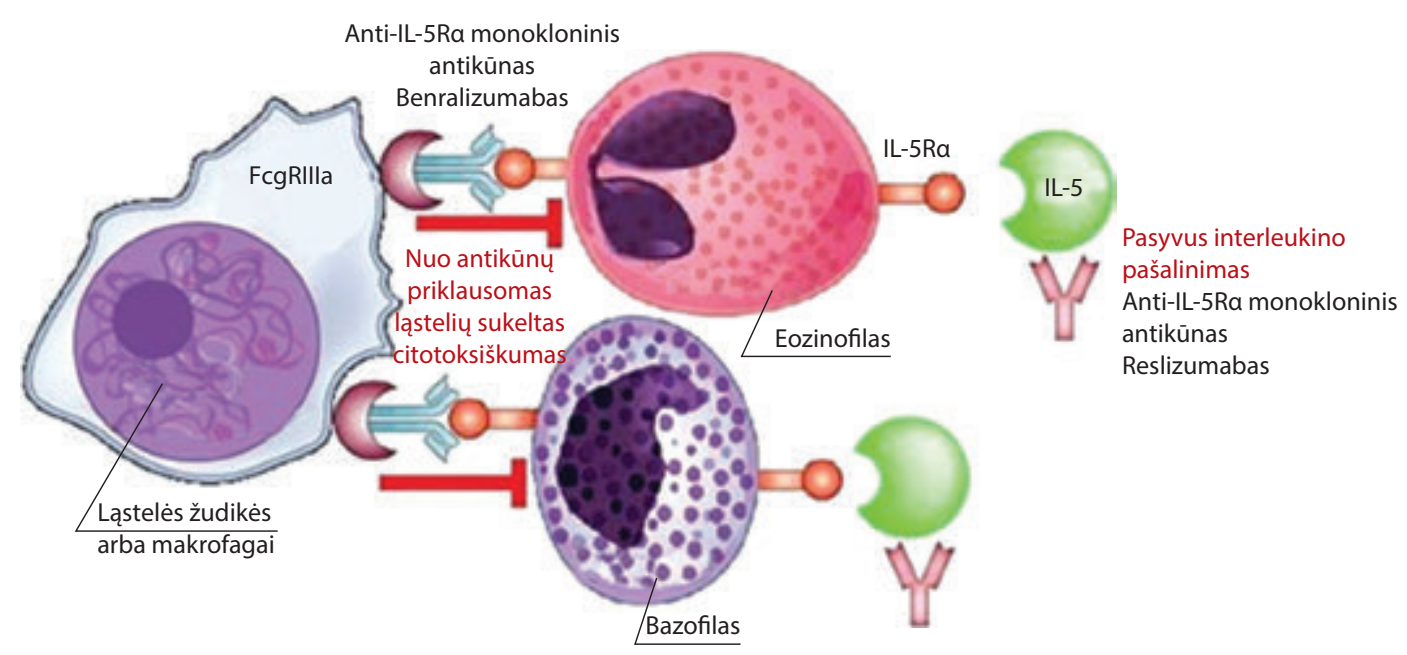

4 pav. Vaistų, nukreiptų prieš IL-5, veikimo mechanizmų principai [41]

FcgRIIla - fragmento imunoglobulino molekulèje, išskirto kristalizuojant mažo afiniteto receptorius IIIA; IL-5 - interleukinas 5; IL-5Ra - interleukino 5 receptorius a grandinè.

\section{EOZINOFILINIO KVĖPAVIMO TAKŲ UŽDEGIMO BIOLOGINIAI ŽYMENYS}

Atsižvelgiant ị sunkios astmos heterogeniškumą, fenotipų gausą ir patogenezès savitumus, gebejjimas priskirti asmenị, sergantị sunkia astma „teisingam“ $\mathrm{fe}$ notipui yra lemiamas tikintis veiksmingo gydymo. Tam tikslui ieškoma biologinių žymenų. Idealus biologinis žymuo turètų išlaikyti aiškų ryšș su ligos patogeneze, būti patikimas ir atkuriamas, kistų gydymo metu, būtų lengvai aptinkamas ir kiekybiškai ịvertinamas, nebrangus ir pasižymètų dideliu jautrumu bei specifiškumu [46, 47].

Šiuo metu klinikinejje praktikoje naudojami eozinofilinio uždegimo biologiniai žymenys yra periferinio kraujo eozinofilų kiekis, periostino koncentracija serume ir azoto oksido frakcija iškvepiamame ore (FeNO). Remiantis naujausiais tyrimais, minètus eozinofilinio uždegimo žymenis kombinuojant su serumo eotaksinų CCL26, CCL17, CCL24 koncentracijomis, sergančiuosius astma būtų galima skirstyti $i$ aukšto ir žemo eozinofilinio uždegimo lygmens fenotipus [48], o tai leistų geriau prognozuoti astmos eigą ir baigtis, gydymo veiksmingumą.

Pagrindiniai eozinofilinio kvėpavimo takų uždegimo biologiniai žymenys:

- Eozinofilų skaičius periferiniame kraujyje:

- eozinofilų išskiriami prouždegiminiai mediatoriai yra pagrindiniai veiksniai, palaikantys kvejpavimo takų uždegimą sergant astma, sukeliantys kvépavimo takų epitelio pažeidimą, cholinerginių receptorių funkcijos sutrikimą, kvejpavimo takų hiperreaktyvumą, padidẻjusią gleivių sekreciją, kvėpavimo takų struktūrinius pokyčius.

- Periostino koncentracija:

- periostinas yra užląstelinio užpildo baltymas, išskirtas iš epitelinių ląstelių kaip atsakas ị įvairius stimulus, įskaitant IL-13, ir jo nustatomas kiekis stipriai koreliuoja su antrojo tipo uždegimu. Periostinas taip pat susijęs su daugeliu uždegiminių procesų sergant astma, pvz., eozinofilų telkimasis plaučiuose, kvépavimo takų struktūriniai pokyčiai (proliferacinis poveikis). Esant didesnei periostino koncentracijai, būna didesnè ir uždegiminių mediatorių raiška.

- IL-13 koncentracija serume:

- svarbiausias citokinas, analizuojant antrojo tipo uždegimą, yra IL-13, kuris dideliais kiekiais gaminamas ILC2 ir Th2 ląstelių bei dalyvauja reguliuojant IgE gamybą, padidèjusią gleivių gamybą, eozinofilu telkimąsi plaučiuose, bronchų hiperreaktyvumą, adhezinių molekulių raišką, chemokinus (pvz., eotaksinus). Pernelyg padidejusi IL-13 raiška sukelia eozinofiliją, gleivių hiperprodukciją ir bronchų hiperreaktyvumą.

- CCL11 koncentracija kraujo serume:

- CCL11 yra citokinas, kuris priklauso CC chemokinų šeimai, dar vadinamas eotaksinu-1. Tai vienas iš trijų pagrindinių eozinofilų chemotaksị didinančių baltymų. Veikia per eozinofilų paviršiuje esančius chemokinų receptorius CCR3 ir skatina eozinofilų telkimąsi plaučiuose.

- CCL17 koncentracija kraujo serume:

- CCL17 yra citokinas, priklausantis CC chemokinų šeimai, kurio gamybą skatina IL-13. CCL17 nerandama sveikų asmenų kraujyje, tačiau didesni kiekiai nustatomi sergant astma. Padidèjusi CCL17 raiška, kartu esant padidejusiam kraujo eozinofilų kiekiui arba 


\section{Moksliniai darbai ir apžvalgos}

FeNO, didina prognostinę vertę, nustatant dominuojantį antrojo tipo uždegimą.

- Eotaksino CCL26 koncentracija serume:

- eotaksinas-3 arba chemokino (C-C) motyvo ligandas 26 (CCL26) yra mažos molekulinès masès citokinas, priklausantis CC chemokinų šeimai. Eotaksiną, esant IL-4 simuliacijai, gamina įvairių organų audiniai: plaučių, širdies ir kiaušidžių bei endotelinès ląstelès. CCL26 yra eozinofilų chemoatraktantas, veikiantis per ląstelių paviršiuje esančius chemokinų receptorius CCR3 ir skatinantis eozinofilu telkimąsi kvèpavimo takuose.

- eotaksino CCL24, dar vadinamo eozinofilu chemotaksiniu baltymu-2 arba eotaksinu-2, koncentracija serume:

- tai chemokino (C-C) motyvo ligandas 24, taip pat priklausantis CC chemokinų šeimai. Yra vienas stipriausių eozinofilų chemoatraktantų, veikiantis per ląsteliu paviršiuje esančius chemokinų receptorius CCR3 ir skatinantis eozinofilų telkimąsi kvèpavimo takuose. Eotaksinas-2 lengvina eozinofilų migraciją. Padidejjus šio chemokino koncentracijai, pastebètas greitesnis eozinofilų adhezijos kelias per ICAM-1 adhezines molekules [49].

\section{APIBENDRINIMAS}

Ilgus metus astmos patogenezè aiškinta dominuojančiu Th2 sukelto alerginio uždegimo pobūdžiu. Pastaraisiais metais nustatyta, kad svarbų vaidmeni vaidina nealerginiu keliu aktyvuojami eozinofilai, kai ILC2 išskiria didelį kiekị IL-5. Eozinofilijos svarbą ligos simptomų pasireiškimui, eigai, atsakui ị skiriamą gydymą šiuo metu geriausiai apibūdina sunkios eozinofilinès astmos fenotipas. Sunkios eozinofilinès astmos metu randami ženklesni struktūriniai kvẻpavimo takų pokyčiai, būdinga sunki ligos eiga, nepalanki prognozè. Situaciją iš esmès keičia klinikiniais tyrimais įrodytas veiksmingas gydymas monokloniniais antikūnais prieš IL-5 - mepolizumabu, benralizumabu, reslizumabu. Svarbi tolesnių tyrinejjimų sritis - skirtinga pačių eozinofilų receptoriu raiška, turinti itakos eozinofilu brendimui, diferenciacijai, migracijai. Kraujo eozinofilų skaičius, periostino koncentracija serume ir FeNO - tai biologiniai žymenys, rodantys kvèpavimo takų eozinofilinio uždegimo intensyvumą. Tyrinejjami ir kiti, galimai jautresni, biologiniai žymenys, pvz., IL-13, CCL11, CCL17, CCL24, CCL26, kurie padètų tiksliau identifikuoti sergančiuosius astma su išreikštu eozinofiliniu kvėpavimo takų uždegimu, prognozuoti gydymo biologiniais vaistais veiksmingumą.

Gauta 20180312

Priimta 20180406

\section{LITERATŪRA}

1. Chung KF, Wenzel SE, Brozek JL, Bush A, Castro M, Sterk PJ, et al. International ERS/ATS guidelines on definition, evaluation, and treatment of severe asthma, 2013. Available from: https://www.thoracic.org/statements/resources/allergyasthma/severe-asthma-full.pdf

2. Biekšienė K, Malakauskas K, red., Danila E, Zablockis R, Blažienè A, Miliauskas S, ir kt. Lietuvos suaugusiujų sunkios astmos diagnostikos ir gydymo rekomendacijos 2017. Pulmonologija ir alergologija. 2017; 1(1):8-16.

3. Buhl R, Humbert M, Bjermer L, Chanez P, Heaney LG, Pavord I, et al. Severe eosinophilic asthma: a roadmap to consensus. Eur Respir J. 2017; 49(5). pii: 1700634.

4. Raundhal M, Morse C, Khare A, Oriss TB, Milosevic J, Trudeau J, et al. High IFN- $\gamma$ and low SLPI mark severe asthma in mice and humans. J Clin Invest. 2015; 125(8):3037-50.

5. Price DB, Rigazio A, Campbell JD, Bleecker ER, Corrigan CJ, Thomas M, et al. Blood eosinophil count and prospective annual asthma disease burden: a UJ cohort study. Lancet Respir Med. 2015; 3(11): 849-58.

6. Lambrecht $\mathbf{B N}$, Hammad $\mathbf{H}$. The immunology of asthma. Nat Immunol. 2015; 16 (1):45-56.

7. Uhm TG, Kim BS. Eosinophil development, regulation of eosinophil-specific genes, and role of eosinophils in the pathogenesis of asthma. Allergy Asthma Immunol Res. 2012; 4(2):68-79.

8. George $\mathrm{L}$, Brightling $\mathrm{ChE}$. Eosinophilic airway inflammation: role in asthma and chronic obstructive pulmonary disease. Ther Adv Chronic Dis. 2016; 7(1):34-51.

9. Johnston LK, Hsu CL, Krier-Burris RA, Chhiba KD, Chien KB, McKenzie A, et al. IL-33 Precedes IL-5 in Regulating Eosinophil Commitment and Is Required for Eosinophil Homeostasis. J Immunol. 2016; 197(9):3445-53.

10. Rosenberg H, Phipps S, Foster P. Eosinophil trafficking in allergy and asthma. J Allergy Clin Immunol. 2007; 119(6):1303-10.

11. Young B, Lowe JS, Stevens A, Heath JW. Wheater's functional histology: A text and colour atlas. 5th ed. Philadelphia [Pa.]: Churchill Livingstone/Elsevier; 2006.

12. Zhang H, Verkman AS. Eosinophil pathogenicity mechanisms and therapeutics in neuromyelitis optica. J Clin Invest. 2013; 123(5):2306-16

13. Doran E, Cai F, Holweg CTJ, Wong K, Brumm J, Arron JR. Interleukin-13 in Asthma and Other Disorders. Front Med (Lausanne). 2017; 4:139. Available at: https://www.frontiersin. org/articles/10.3389/fmed.2017.00139/full

14. Wagner LA, Christensen CJ, Dunn DM, Spangrude GJ, Georgelas A, Kelley L, et al. EGO, a novel, noncoding RNA gene, regulates eosinophil granule protein transcript expression. Blood. 2007; 109(12):5191-8.

15. Rothenberg M, Hogan S. The eosinophil. Annu Rev Immunol. 2006; 24(1):147-74.

16. Davoine F, Lacy P. Eosinophil cytokines, chemokines, and growth factors: emerging roles in immunity. Front Immunol. 2014; 5:570.

17. Rosenberg HF, Dyer KD, Foster PS. Eosinophils: changing perspectives in health and disease. Nat Rev Immunol. 2013; 13(1):9-22.

18. Tartibi HM, Bahna SL. Clinical and biological markers of asthma control. Expert Rev Clin Immunol. 2014; 10(11):1453-61.

19. Izuhara K, Arima K, Ohta S, Suzuki S, Inamitsu M, Yamamoto K. Periostin in allergic inflammation. Allergol Int. 2014; 63(2):143-51.

20. Conway SJ, Izuhara K, Kudo Y, Litvin J, Markwald R, Ouyang $\mathrm{G}$, et al. The role of periostin in tissue remodeling across health and disease. Cell Mol Life Sci. 2014; 71(7):1279-88.

21. Januskevicius A, Gosens R, Sakalauskas R, Vaitkiene S, Janulaityte I, Halayko AJ, et al. Suppression of Eosinophil Integrins Prevents Remodeling of Airway Smooth Muscle in Asthma. Front Physiol. 2017; 7:680.

22. Possa SS, Leick EA, Prado CM, Martins MA, Tibério IF. Eosinophilic inflammation in allergic asthma. Front Pharmacol. 2013; 4:46.

23. Steinke JW, Borish L. Th 2 cytokines and asthma - Interleukin-4: its role in the pathogenesis of asthma, and targeting it 


\section{Moksliniai darbai ir apžvalgos}

for asthma treatment with interleukin-4 receptor antagonists. Respir Res. 2001; 2(2):66-70.

24. Dunican EM, Fahy JV. The Role of Type 2 Inflammation in the Pathogenesis of Asthma Exacerbations. Ann Am Thorac Soc. 2015; 12(2):S144-9.

25. Walford HH, Doherty TA. Diagnosis and management of eosinophilic asthma: a US perspective. J Asthma Allergy. 2014; 7:53-65.

26. Wenzel SE. Asthma phenotypes: the evolution from clinical to molecular approaches. Nat Med. 2012; 18(5):716-25.

27. Koczulla AR, Vogelmeier CF, Garn H, Renz H. New concepts in asthma: clinical phenotypes and pathophysiological mechanisms. Drug Discov Today. 2017; 22(2):388-96.

28. Poon AH, Eidelman DH, Martin JG, Laprise C, Hamid Q. Pathogenesis of severe asthma. Clin Exp Allergy. 2012; 42(5):625-37.

29. Mjösberg JM, Trifari S, Crellin NK, Peters CP, van Drunen CM, Piet B, et al. Human IL-25- and IL-33-responsive type 2 innate lymphoid cells are defined by expression of CRTH2 and CD161. Nat Immunol. 2011; 12(11):1055-62.

30. Walker JA, Barlow JL, McKenzie AN. Innate lymphoid cells-how did we miss them? Nat Rev Immunol. 2013; 13(2):75-87.

31. Spits H, Artis D, Colonna M, Diefenbach A, Di Santo JP, Eberl G, et al. Innate lymphoid cells--a proposal for uniform nomenclature. Nat Rev Immunol. 2013; 13(2):145-9.

32. Barnig C, Cernadas M, Dutile S, Liu X, Perrella MA, Kazani $S$, et al. Lipoxin A4 regulates natural killer cell and type 2 innate lymphoid cell activation in asthma. Sci Transl Med. 2013; 5(174):174ra26

33. Moffatt MF, Gut IG, Demenais F, Strachan DP, Bouzigon E, Heath S,et al. A large-scale, consortium-based genomewide association study of asthma. N Engl J Med. 2010; 363(13):1211-21.

34. Brusselle GG, Maes T, Bracke KR. Eosinophilic airway inflammation in nonallergic asthma. Nat Med. 2013; 19(8):977-9.

35. Kankaanranta $H$, Lindsay MA, Giembycz MA, Zhang $X$, Moilanen E, Barnes PJ. Delayed eosinophil apoptosis in asthma. J Allergy Clin Immunol. 2000; 106(1 Pt 1):77-83.

36. Mesnil C, Raulier S, Paulissen G, Xiao X, Birrell MA, Pirottin $D$, et al. Lung-resident eosinophils represent a distinct regulatory eosinophil subset. J Clin Invest. 2016; 126(9):3279-95.

37. Holgate ST, Polosa R. Treatment strategies for allergy and asthma. Nat Rev Immunol. 2008; 8(2):218-30.

38. Barnes PJ. Mechanisms and resistance in glucocorticoid control of inflammation. J Steroid Biochem Mol Biol. 2010; 120(2-3):76-85.

39. Matthews JG, Ito K, Barnes PJ, Adcock IM. Defective glucocorticoid receptor nuclear translocation and altered histone acetylation patterns in glucocorticoid-resistant patients. J Allergy Clin Immunol. 2004; 113(6):1100-8.

40. Barlow JL, Peel S, Fox J, Panova V, Hardman CS, Camelo A, et al. IL-33 is more potent than IL-25 in provoking IL-13-producing nuocytes (type 2 innate lymphoid cells) and airway contraction. J Allergy Clin Immunol. 2013; 132(4):933-41.

41. Tan LD, Bratt JM, Godor D, Louie S, Kenyon NJ. Benralizumab: a unique IL-5 inhibitor for severe asthma. J Asthma Allergy. 2016; 9:71-81.

42. Nair $P$, Pizzichini MM, Kjarsgaard $M$, Inman MD, Efthimiadis A, Pizzichini E, et al. Mepolizumab for prednisonedependent asthma with sputum eosinophilia. N Engl J Med. 2009; 360(10):985-93.

43. Haldar P, Brightling CE, Hargadon B, Gupta S, Monteiro W, Sousa A, et al. Mepolizumab and exacerbations of refractory eosinophilic asthma. N Engl J Med. 2009; 360(10):973-84.

44. Castro M, Wenzel SE, Bleecker ER, Pizzichini E, Kuna P, Busse WW, et al. Benralizumab, an anti-interleukin 5 receptor a monoclonal antibody, versus placebo for uncontrolled eosinophilic asthma: a phase $2 \mathrm{~b}$ randomised dose-ranging study. Lancet Respir Med. 2014; 2(11):879-90.

45. Castro M, Zangrilli J, Wechsler ME, Bateman ED, Brusselle GG, Bardin P, et al. Reslizumab for inadequately controlled asthma with elevated blood eosinophil counts: results from two multicentre, parallel, double-blind, randomised, placebocontrolled, phase 3 trials. Lancet Respir Med. 2015; 3(5):355-66.

46. Yancey SW, Keene ON, Albers FC, Ortega H, Bates S, Bleecker ER, et al. Biomarkers for severe eosinophilic asthma. J Allergy Clin Immunol. 2017; 140(6):1509-18.

47. Poon AH, Hamid Q. Severe asthma: have we made progress? Ann Am Thorac Soc. 2016; 13(1):S68-77.

48. Silkoff PE, Laviolette M, Singh D, FitzGerald JM, Kelsen S, Backer V, et al. Identification of airway mucosal type 2 inflammation by using clinical biomarkers in asthmatic patients. J Allergy Clin Immunol. 2017; 140(3):710-19.

49. Tachimoto H, Kikuchi M, Hudson SA, Bickel CA, Hamilton RG, Bochner BS. Eotaxin-2 alters eosinophil integrin function via mitogen-activated protein kinases. Am J Respir Cell Mol Biol. 2002; 26(6):645-9. 